\title{
LOVE, ANGER, AND RACIAL INJUSTICE ${ }^{1}$ Myisha Cherry
}

\author{
(Forthcoming in Adrienne Martin's THE ROUTLEDGE \\ HANDBOOK OF LOVE IN PHILOSOPHY, Routledge: 2019)
}

Luminaries like Martin Luther King, Jr. urge that Black Americans love even those who hate them. This can look like a rejection of anger at racial injustice. We see this rejection, too, in the growing trend of characterizing social justice movements as radical hate groups, and people who get angry at injustice as bitter and unloving. Philosophers like Martha Nussbaum argue that anger is backwardlooking, status focused, and retributive. Citing the life of the Prodigal Son, the victims of the Charleston Church shooting, Gandhi, and King, she claims that we should choose love instead of anger - not only in our intimate relationships but also in the political realm. Buddhist monk and scholar, Shāntideva, argued that anger is an obstacle to love. Anger leads to suffering. Love frees us from suffering. All this makes an initially compelling case against anger at racial injustice. In addition, although philosophers Jeffrie Murphy and Antti Kauppinen argue that anger communicates self-respect and valuing, respectively, they make no connection between agape love and anger. In this essay I'll show that the love King and others have in mind - agape love - is not only compatible with anger at hateful racists and complicit others, but finds valuable expression in such anger.

\section{Agape Love}

I will begin first by providing an account of agape love and showing why it is an apt response in a political context. 
The ancient Greeks made distinctions between three kinds of love: eros, philia, and agape (May 2011; Lindberg 2008). Eros is sexual love and it is experienced between romantic partners. Philia is brotherly love and it is experienced between friends. Agape love is usually referred to as "divine love" because it is the kind of love that God has for humans. In this essay I use love in the sense of agape. The reason for this may not be, at first, so apparent. One may immediately realize that I have omitted eros from a discussion about racial injustice. The moral relationship that I am interested in is not one between sexual lovers but between community members. Sex and sexual attraction, although a topic worthy of a discussion for reasons beyond the philosophical, is irrelevant to my project. However, what may be more puzzling is why I have chosen to omit brotherly love from a conversation that involves our fellows. In addition, agape love, some may say, is divine love and thus, is a kind of love that only God can give. It is a love that humans can only aspire to but not actually achieve. Therefore, some may claim that through my use of agape I am focusing on an ideal that humans are incapable of extending to others. Since philia focuses on friendship, philia is the kind of love that humans can give. Such a love, the puzzled may say, is apt for this discussion.

However, I choose to focus on agape love instead of philia for several reasons. First, philia entails mutuality. I cannot have philia for Jason, for example, if he does not have philia for me. Perhaps it is because we have never met or he does not have a desire to be friends with me. I can have philia for Jason only if he also has it for me. I think this will make love impossible for those who choose to love their enemies because they will be unable to love enemies who do not love them back. Second, it is a generally accepted view that philia responds to the good qualities in the beloved (Helm 2013). I can love Jason because he is generous, hardworking, and smart. If Jason does not have these 
qualities, I may not love him. In a context of injustice, there are agents who express racist attitudes, create unjust policies, and are complicit in unjust treatment. It may be difficult to find good qualities to love in them. Third, as it relates to agape love, we do not have to accept the divine condition. In other words, we can take a secular view toward agape and view it as unconditional love. Agape is not an ideal. It entails loving a person for their own sake and not because certain conditions have been met. Contrary to philia, me loving Jason (extending agape love) does not depend on Jason loving me. It does not depend on Jason having good qualities. I love Jason because of his humanity. This kind of love is possible and appropriate in a political context.

Agape love is also different from eros and philia in that agape is impartial and directed to all. Eros and philia are both partial and directed only toward particular people. My philia for Jason aims at Jason and Jason alone. However, agape is universal and impartial. It aims at Jason but not Jason alone. It also aims at Jesús, Jamaal, Jin, and Josefina.

I find Martin Luther King, Jr.'s account of agape love quite persuasive. For King, agape is not an affectionate feeling nor does it require "liking" the beloved. Instead, love is an attitude. The reason for loving the beloved is unmotivated and groundless, therefore agape is not aimed at a selective few but rather all members of the moral community. ${ }^{2}$ It involves understanding, goodwill, respect, and active concern. Agape is not passive or weak but active and tough. It desires the common good, resistance to injustice, and restoration of the beloved community. Although agape is generalized love toward everyone, it is often expressed differently to particular people.

Robert Solomon thinks agape love is another word for compassion, conceived along the lines of Adam Smith's "sympathy," or "affectionate fellowfeeling." For Solomon, then, agape love is a "gut feeling ... an affective response 
that consists of feeling sorrow or concern for the distressed or needs of others. It also involves distinctive action tendencies, namely, helping." He continues, "It is compassion [or love], this ability to feel for those less fortunate than oneself, that I would argue is the cornerstone passion of our sense of justice" (Solomon 2007: 66). Solomon's reading of Smith is nuanced but, for purposes of this chapter, I choose to take Smith at his word and conclude that sympathy is not compassion, but something closer to the contemporary concept of empathy. Smith explicitly makes a distinction between sympathy and compassion.

Pity and compassion are words appropriated to signify our fellowfeeling with the sorrow of others, sympathy, though its meaning was, perhaps, originally the same, may now, however, without much impropriety, be made use of to denote our fellow-feeling with any passion whatever.

(Smith 1976: 49)

Compassion is our fellow-feeling with sorrow. Sympathy, for Smith, is fellowfeeling with any passion. Most importantly, agape love is not only compassion or only sympathy, but rather incorporates and extends both compassion and sympathy.

For King, at the heart of agape love is creative understanding giving rise to sympathy/empathy, and thereby Smithian compassion. King claims that agape is more than sentimental outpouring. Liking the beloved is not what defines the love. Liking is a sentimental and affectionate activity. He notes this kind of affection is impossible to extend toward an enemy that bombs your home or crushes your soul. Liking is more akin to philia. Agape, however, is greater than liking. King defines agape as "understanding and creative, redemptive goodwill for all men" (King and West 2015: 59). Here King differs from Solomon in that he thinks agape involves Smithian sympathy: an empathetic understanding that 
comes as a result of putting oneself in the shoes of others as if we were them. Agape involves seeking to understand the other from their shoes. King extended agape during the Montgomery bus boycott. After the bombing of his home in 1956, he extended creative understanding. He writes:

I tried to put myself in the place of the three commissioners. I said these men are not bad men ... they have fine reputations in the community. ... They say the things they say about us and treat us as they do because they have been taught these things. ... The whole cultural tradition under which they have grown ... teaches them that Negroes do not deserve certain things.

(King and West 2015: 11)

Through agape, King was able to understand what it was like to be in the shoes of the commissioners. Understanding the commissioners from his own shoes would have been easy for King. However, understanding the commissioners in their shoes took a creative understanding. He recognized that this understanding was part of loving them. On the basis of this understanding, King was able also to have compassion for commissioners. Agape for King is "(an) attitude of respect and active concern, one that seeks a common good in which all are included" (Nussbaum 2016: 222).

Another important feature of King's agape love is that it is "spontaneous, unmotivated, groundless." In particular, and in contrast with philia, it does not depend on reciprocity from the beloved. While Smith notes that sympathy is often biased toward those within our close circles, agape for King "makes no distinction between friend and enemy; it is directed towards both." Agape does not aim at loving only one person; agape seeks to restore the moral community. Instead of seeing people as distant others, "agape means the recognition of the 
fact that all life is interrelated" (King and West 2015: 51, 52). Through agape, we recognize that harm to our neighbour also harms us.

Agape is also active and reconciling. King notes, "when I am commanded to love, I am commanded to restore community, to resist injustice, and to meet the needs of my brothers." Agape thus has an aim: restoration of the beloved community. A person who has agape love "goes the second mile to restore community" (King and West 2015: 52). This desire for restoration, resistance to injustice, and loving attitude toward an enemy show that agape is not weak or passive. It is rather tough and uncompromising.

A popular criticism of King's demonstration of agape love through rhetoric and non-violent action is that it is too self-sacrificial and so other-regarding that it compromises self-respect and self-love (Malcolm X and Breitman 1990). In my recast of his account here, there is no mention of the self. The implication could be that the self, particularly when oppressed, is not worth the same as the others they are encouraged to love. However, we ought not to think the self is unimportant in agape.

First, if one has little regard for oneself, one is not likely to have much regard for others. Hence the Christian commandment that one ought to love thy neighbor as one loves oneself. James Baldwin articulates this idea in The Fire Next Time when he writes that the Negro problem would not be solved until white people begin to love themselves. The idea behind Baldwin's claim is that racism exists not because whites have an extreme form of self-love but because they lack it. Assuming that racist attitudes are, among other things, a failure of agape love, we could draw from Baldwin to reason that agape in fact presupposes self-love. This does not mean that a person should love themselves in order to love others. Rather, it suggests that the person cannot extend agape love until they love themselves. 
Second, influenced by the Black Consciousness Movement, the later King often emphasized the importance of blacks being proud of themselves. In his speech "Where Do We Go From Here" he encouraged them to embrace the mantra "I'm black and I'm beautiful." King did not see the encouragement of self-love and self-respect as irrelevant or a contradiction to agape. For this reason, I am inclined to think that agape not only requires self-love but is the playground for it. The practice of agape love helps one avoid both the death trap of selfhatred and the excess of narcissistic self-love.

Third, agape is an attitude concerned with the community - a community where the self and others exist. You, too, are a member of the moral community; you owe yourself the same regard, concern, and understanding that you owe anyone else. Thus, concern for the self-or, more directly, self-care-enters into agape love along multiple avenues.

\section{Moral Anger}

In what follows, I will argue that anger is a judgment that one has been wronged; it is aimed at leveling the wrongdoer's status with one's own by negating the wrongdoer's implicit assertion of superiority; and aimed further at changes to any societal structures that affirm the false notion that the wrongdoer or people of the wrongdoer's social class are superior. One will recognize that some of the themes presented in my aforementioned account of agape reoccur in my account of moral anger. This, I hope, will convince you not only of agape and moral anger's similarities but also their compatibility.

On a cognitive view of the emotions, anger is the judgment that an offense or wrong has occurred. Solomon and others therefore view anger as a judgmental emotion. It is a judgmental emotion in two ways: it is structured by judgments (ways of evaluating the world) and it involves a particularly judgmental stance toward the world (Solomon 2007: 24). When a person is angry about a 
wrongdoing in which she is the victim, for example, she judges that a wrong has been committed against her. In anger, the offender is put on trial. Moreover, anger, by definition, places the angry person in the position of a magistrate. The offense knocks the victim down but the judgmental stance places the victim in the authoritatively superior role of judge and jury. Through this process, the angry victim "emerges from a situation in which one has been hurt, offended or humiliated, one repositions oneself as superior, even as righteous" (Nussbaum 2016: 28).

Martha Nussbaum claims that anger commits the error of status-focus. Status-focus occurs when the victim sees the events as being all about them and their rank (Nussbaum 2016: 28). They zero in on the fact that the offender has humiliated or disrespected them, and focus on bringing the offender down. However, I think that this criticism of anger is not a proper description of the phenomenon. If an offender has harmed another, surely the offender is brought down. Nussbaum thinks the offender is brought "beneath" the victim. I disagree. Perhaps through anger, the angry agent brings the wrongdoer from a position of superiority - from which the wrongdoing occurs - to a position of equality. This equality is not one of pain but one of status. A wrongdoing communicates that, "You or others do not matter-I may treat you however I choose." Anger communicates, "I do not accept this message" (Murphy 2003: 35). Adopting the stance of the authoritatively "superior" magistrate is thus actually a way to assert equal status - the offender is brought down to a level of equality in which the angry agent reminds the wrongdoer of their human failure and thus their humanity, but also their equality with others.

Audre Lorde claims that anger's object "is change." A person who is angry about racial injustice, for example, does not necessarily have as their goal the desire to pay society back but may rather seek to transform it. An angry 
protestor who marches against racial injustice is angry and as a result wants to raise awareness and pressure the authorities to enact change. Here we see that their anger is not about revenge but reform. While critics claim that anger is destructive, Lorde claims that it is not our anger that will destroy us, but rather our "refusals to stand still, to listen to its rhythms, to learn within it ... to tap it as an important source of empowerment" (Lorde 2007: 282).

Joseph Butler thinks that what is problematic about anger is not anger but its abuses. Abuses of resentment for Butler include: imagining the injury, being partial, having a resentment that arises without a reason, having a disproportionate resentment, or an out-of-control outrage. Butler believes that moderate resentment is acceptable and has utility. He writes,

When this resentment entirely destroys our natural benevolence towards him, it is excessive and becomes malice and revenge ... resentment should be used in order to produce some greater good ... and must not be indulged or gratified for itself.

(Butler: Sermon IX)

Here Butler is making a distinction between two different types of anger: sudden anger and deliberate anger. The only anger he argues against is sudden anger. On Butler's account, deliberate anger can be a rational and appropriate response to racial injustice.

Thus characterized, moral anger is a virtue - that is, in Aristotle's terms, anger at the right time, about the right thing, toward the right people, and for the right end. There are thus several vectors along which anger can fail to be virtuous. The most worrisome failures of this virtue are that it can aim at the wrong end; not correcting false claims of superiority; or not changing societal structures that affirm false claims. 


\section{The Compatibility Argument}

Given that moral anger is a virtue and therefore not conceptually about destruction, I will show, following Joseph Butler and James Baldwin, that love and anger are compatible. I will first describe two versions of the incompatibility arguments. I will then respond to them by explicating Butler's and Baldwin's compatibility arguments with the aim of showing that moral anger and agape are compatible because both have the same aims and anger can even further agape's end.

Aristotle notes, "Let anger be a desire accompanied by pain for a noticeable revenge ... and always accompanying anger is a certain pleasure for the hope of revenge" (Aristotle 2004: 1378a37-b15). Here Aristotle explicitly makes a connection between resentment and revenge. For him, anger does not just lead to revenge; it entails a hope for revenge. Influenced by Aristotle, Nussbaum thinks we should opt for love instead of anger because love does not conceptually have this hope for or pleasure in revenge. On her view, this desire for retribution helps us to see "the irrationality and stupidity of anger." She recommends, "When there is a great injustice ... (the) end goal must remain ... agape" (Nussbaum 2016: 249). Nussbaum does not admit of anger and love's compatibility and thus claims that anger involves desires that are contrary to the love ethic.

This incompatibility argument is also present in the Buddhist tradition (Flannigan 2018). Typical Buddhist moral pharmacology suggests that anger is produced by self-ego, self-ego is part of an illusion, and this illusion contributes to suffering. If the aim of ethics is to overcome suffering, anger is the opposite of ethics because it produces suffering. However, love is unselfish and it aims for the happiness of others. Thus, anger and love cannot go together. Anger is an 
obstacle to love. It causes harm, is fueled by hate, and prevents us from seeing others.

However, Baldwin and Butler argue that love and anger are compatible. In doing so, they not only provide new insights into the compatibility but they also respond to the revenge and self-ego concerns raised in the incompatibility arguments.

Joseph Butler writes:

Resentment is not inconsistent with goodwill; for we often see both together in very high degrees, not only in parents towards their children, but in cases of friendship and dependence, where there is no natural relation. These contrary passions, though they may lessen, do not necessarily destroy each other. We may therefore love our enemy, and yet have resentment against him for his injurious behavior towards us.

(Butler 1827: Sermon IX)

If anger's goal, according to Butler, is to recognize a moral injury, prevent it, and have a desire that the injury be punished, then it is consistent with agape love because the anger contributes to goodwill. How can an agent have resentment toward her fellow and still love him unconditionally? It is because her anger can serve as a way to prevent the fellow from harming others; for in harming others he also harms himself. The anger in the passage above is not concerned with revenge. Rather it aims for reform. If agape is an attitude that also aims for reform, we can begin to see how anger and agape are compatible.

Given the historical and present-day injustices that blacks experience in the U.S., Baldwin recognized that "to be a Negro in this country and to be relatively conscious is to be in rage almost all the time." He continues: 
There is not a Negro alive who does not have this rage in his bloodone has the choice, merely, of living with it consciously or surrendering to it. As for me, this fever has recurred in me, and does, and will until the day I die.

(Baldwin 1984: 94)

Lorde echoes this phenomenon when she notes that "every black woman in America lives her life somewhere along a wide curve of ancient and unexpressed angers" (Lorde 2007: 146).

However, for Baldwin, blacks are not only angry with their American fellows for their perpetuation of injustice. Blacks also have love for them. ${ }^{3}$

No one in the world-in the entire world-knows more-knows Americans better or, odd as this may sound, loves them more than the American Negro. This is because he has had to watch you, outwit you, bear you, and sometimes even bleed and die with you ever since we got here, that is since both of us, black and white, got here - and this is a wedding.

(Baldwin 1998: 243)

When Baldwin pens "A Letter for my Nephew," he instructs his nephew to accept white fellows "in love" and that this love "shall force our brothers to see themselves as they are" (Baldwin 1993: 8, 10). Baldwin's use of "brother" is not alluding to philia. It is rather a familial term. As Douglas Fields puts it, Baldwin's love was "not sentimentality," it was "explicitly active and political" (Fields 2015: 95, 96). Baldwin was intent on loving the family for whom his affection lies: his American family, but this does not mean that agape love should only be extended to Americans. On the contrary, it was extended not because they were Americans but in spite of that fact. 
How can blacks have anger toward their white fellows and still love them? As Lorde argues, anger used does not destroy. Anger's object is change. Similarly, agape desires resistance to injustice and restoration, not destruction of a better future for us all. Anger and love are also active and not passive. In this sense, anger can be used in the service of agape; for in desiring resistance to injustice through agape, anger can help achieve that goal. They both oppose the message of racial superiority and social structures supporting the message.

Lastly, agape and moral anger are compatible in that they have the same aim: to drive out hate. To that end, love and anger are not incompatible. To the contrary, moral anger at racial injustice and racial hatred are incompatible. Solomon hints at this when he notes that Nussbaum's and Aristotle's criticisms are actually targeted at "protracted anger," which tends "towards hatred and manifested in schemes of retaliation and vengeance" (Solomon 2007: 18). This is also why, for Baldwin, blacks are able to have rage and yet love their white fellows. Throughout his essays, Baldwin criticizes anger only when it is tied to hate. This is because moral anger is distinct from the racial hatred that "protracted anger" tends toward. Lorde notes that hatred and anger are very different. "Hatred is the fury of those who do not share our goals, and its object is death and destruction. Anger is the grief of distortions between peers, and its object is change" (Lorde 1997: 282). She makes a further distinction in "Eye to Eye."

Anger - a passion of displeasure that may be excessive or misplaced but not necessarily harmful. Hatred - an emotional habit or attitude of mind in which aversion is coupled with ill will. Anger, used, does not destroy. Hatred is a death wish for the hated, not a life wish for anything else.

(Lorde 2007: 152) 
Also, hate is more passive because it does not believe it can change anything. On the other hand, anger is active and it makes the agent believe it can change the situation (Aarts et al. 2010). The crucial contrast between hatred and moral anger is the end or aim of the attitude. Hate seeks to eliminate the hated person rather than opposing their message of racial superiority or the social structures supporting that message. Moral anger at racial injustice instead aims for political reconciliation and change.

Agape love, too, is the enemy of hate. In his sermon, "Love Your Enemies," King admonishes his listeners to fight hate with love. He recommends that they do not return hate with hate. Only love can drive out the hate of their enemies. King believed that hate scars the soul and is injurious to the person who hates. Believing that agape love was the opposite of racial hatred, he recognized that hate divides the personality but love unites it. King was emphatic about eliminating hate because he understood that racial hatred is the negation of agape love. Hate's presence will prevent them from achieving justice and political reconciliation.

While agape love seeks understanding, hate does not want to understand. Hate's global evaluation of the hated object focuses on the negative aspects of the object's personality. While doing so, other traits are rendered insignificant (BenZe'ev 2001: 382). In the case of King and the commissioners, instead of seeking to understand racists through agape love, racial hatred would have led him to focus only on racists' negative actions and view racists only in light of them. Hate often feeds off false information and ignores the person's whole character. Those who hate an object think the object possesses some inherent traits that warrant their hatred. However, through agape love, we apply an empathetic understanding to our enemies. King believed that circumstances and culture had an impact on his enemies' racist behavior. He believed that the person was not inherently evil. 
Because they are not inherently or absolutely evil, King believed they still had a conscience that could be persuaded through love.

Agape love aims for community. However, hate involves a wish to eliminate the object. The object of hate is not change or reconciliation. The person who hates believes the only solution is elimination. "To hate someone is to feel irritated by his mere existence. The only thing that would bring satisfaction would be his total disappearance" (Ben-Ze'ev 2001: 379). Such hate leaves no room for agape love.

Thus, agape and anger both aim to drive out hate, while hate aims only to eliminate others. Hatred is thus incompatible with agape love. It is also destructive of agape love and moral anger's ends.

\section{Moral Anger as an Expression of Agape Love}

Having argued that virtuous, moral anger is not only compatible with agape love, but can also further its ends, I will now argue further that moral anger is an expression of agape love. By "expression," I mean that moral anger communicates or demonstrates agape love.

Jeffrie Murphy thinks that anger expresses respect for the wronged party. He notes that wrongdoing conveys a message to the victim that they do not matter. Resentment of the wrongdoer communicates that one does not endorse that message. When a person too willingly gives up their resentment, Murphy believes they are not practicing the virtue of forgiveness but instead are practicing the vice of servility (Murphy 2003: 77). He thinks that indignation at the injury of others is an emotional testimony that you care about them. Resentment at the injustice one experiences is an emotional testimony that one cares about oneself.

Antti Kauppinen argues that anger demonstrates that we care for each other and care about caring. On his view, to value a personal relationship is to 
care for it, be emotionally vulnerable to its fortunes, and to care for the other person in the relationship. Such valuing involves other-directed expectations such as the expectation that our friends will be attentive to our needs and that they will refrain from hurting the relationship. It also involves us paying attention to how they fare and holding them accountable. He writes, "When what we value is genuinely valuable, these normative expectations are appropriate and anger [at their violation] fitting" (Kauppinen 2018: 42). While I find these philosophers' insights illuminating, I do not think that anger only communicates self-respect or valuing; this view tells only part of the story. ${ }^{4}$ While Kauppinen's concern for valuing is closer to the domain of love, his argument is directed toward personal relationships. He does not account for valuing other relationships such as civic and political relationships. I think my account does.

In this section, I will argue that anger at racial injustice expresses agape love for all and this includes: (1) those who perpetrate racial injustice - even those who do so out of hatred and who, therefore, themselves are incapable of holding Black Americans in agape love; (2) the hated; and (3) the moral community in general. This does not mean that agape love moves from the universal into the particular and thus becomes philia. Rather, it means that agape love manifests in different varieties, but the ends of agape are always the same. Most of my argument will motivate the first claim but we need not think that it is the most important claim.

If I aim to have the agape love that King describes, this will express itself through moral anger at those who hate as well as those who create unjust policies and are complicit in racial injustice. This is because moral anger expresses active concern for the moral improvement of those not only who are resistant to racial injustice, but also those who perpetuate it, or are complicit in it. 
Love is tough and uncompromising. There is nothing tougher than our angry feelings. This is because wrongdoers are incentivized to repent and reform in confronting resentment. In being morally angry, we contribute to the wrongdoer's moral perfection by proclaiming that the moral injury is not OK. We also contribute to their moral improvement by using our anger as a way to incentivize others to not harm. Out of a desire for racists' moral perfection, the moral anger can serve as a preventative method that motivates the potential wrongdoer.

Through anger, we show those we love that we are not only concerned about their treatment of others and ourselves but that we are also concerned for their moral well-being. If we often learn or are deterred by anger, blame, and punishment, it is in the racist's best interest that we respond with anger when they perform moral wrongs. Moreover, the more we love the offender, the more we can get angry with them. This anger does not mean we want to destroy them or make them suffer but it means we want them to do better. It is, as Butler notes, only when this anger "entirely destroys our natural benevolence towards him, it is excessive, and becomes malice or revenge" that we should not have it or endorse it (Butler 1827: Sermon IX). That is why Baldwin warns us about this kind of anger. He notes: "One of the necessities of being black and knowing it, is to accept the hard discipline of learning to avoid useless anger" (Baldwin 1998: 562). But useful moral anger is concerned with and contributes to a wrongdoer's moral well-being.

Moral anger at injustice is a form of criticism. This criticism is not destructive but constructive. It shows that the object of anger has work to do. Baldwin had no problem criticizing America (with anger) because he knew it was out of love. Love is about truth telling. The tradition of black letters is filled with stories, essays, and plays "telling it like it is." As much as black letters paint a 
picture of black life, they put a mirror to the faces of white Americans. It is this criticism (often expressed in an angry tone) that is essential to love. Those who love you are willing to tell you the truth about yourself. Baldwin knew that criticism fused with truth and accountability was an act of agape love. He writes: "I love America more than any other country in the world, and, exactly for this reason, I insist on the right to criticize her perpetually" (Baldwin 1984: 9). This anger is truth-telling.

Whether I like it or not, or whether you like it or not, we are bound together forever. We are a part of each other. What is happening to every Negro in the country at any time is also happening to you. There is no way around this. I am suggesting that these walls - these artificial walls - which have been up so long to protect us from something we fear, must come down.

(Baldwin 1998: 234)

Baldwin's angry criticism was because Americans did not understand how interrelated they were with the oppressed. What we do to one group, we do to all. He aimed his anger at white Americans in order to get them to see how they were hurting themselves through hate. If we love, then we will express anger. Baldwin loved and as a result he expressed anger.

Moral anger also expresses agape love when it communicates respect. As King notes, agape love is an attitude of respect. The respect that King describes is recognition-respect. Having this kind of respect is to recognize that the other has equal moral standing. The respect one accords to another is not because they have certain qualities but because of their humanity. If respect is a form of recognition, then moral anger expresses respect by recognizing that the racist and complicit others' actions matter in the world. As Robert Brandom notes, "To recognize someone is to take her to be the subject of normative statuses, that is, 
of commitments and entitlements, as capable of undertaking responsibilities and exercising authority" (Brandom 2007: 136). When we hold people to account (which anger aims to do), we recognize them as moral agents; as humans who have commitments and responsibilities and who act in the world. In addition, because moral anger is not only a form of protest but also a moral argument, such anger expresses the respectful element of agape by showing that despite what anyone has done, they are still human. It expresses that they should not be humiliated but rather challenged or persuaded as humans with equal moral standing.

Not only does moral anger express agape for those who hate; it also expresses love for the hated. As mentioned earlier, anger at a wrongdoing communicates that a victim matters. My anger shows that I do not endorse that message. Thus, in being angry, I show or express respect to the victim and I express self-respect when I am the victim.

Also, if agape love recognizes that life is interrelated, as Baldwin argues above, then by sharing in fellow-feeling through moral anger, the angry expresses agape love. Butler writes:

It is resentment against vice and wickedness: it is one of the common bonds, by which society is held together; a fellow feeling which each individual has on behalf of the whole species, as well as of himself.

(Butler 1827: Sermon VIII)

Here Butler appears to think that resentment is a fellow-feeling that holds a society together. His use of fellow-feeling is similar to Smithian sympathy. Through sympathy, we imagine what it would feel like to experience the moral injury and we get angry. We feel the anger that we also see in the victim (although not to the same degree) or the anger that the injured would or should feel given the moral injury that was committed. This fellow-feeling bonds society- 
members because it connects them to each other's experiences of harm. In this way, no one suffers alone. Through fellow-feeling the morally angry expresses the interrelatedness of their lives. Their anger displays that when one is injured, "we all feel it." In addition, the victim's victimhood is validated by the united indignation raised by the injustice. We express our active concern, respect, and solidarity for injured members of the community when we express anger in response to their experiences of injustice. We also confirm their right to be angry through the sharing in the fellow-feeling of indignation. The validation of both victimhood and the victim's emotional response to it, as well as fellow-feeling, expresses agape in ways that unite the moral community.

Lastly, moral anger at racial injustice committed against another also expresses love in that it shows that we have the moral community's best interest in mind. This is because moral anger aims for justice. When one is angry at the injustice experienced by another, one desires and is motivated to seek justice on the person's behalf. This is what agape love is. On King's account, love is resisting injustice. While reason may be important to creating laws, moral anger is what motivates us to bring the offender to justice. When I am angry at the moral injury done to you, not only have I judged that a moral injury has occurred but also I am often motivated to pursue justice. I display the attitude of respect and active concern that makes agape love. In demanding and seeking justice on behalf of the individual, my moral anger also has other members of the moral community in mind. Agape love seeks the common good in which all are included.

Racial wrongs not only humiliate and harm certain groups but also prevent the formation of community; a community that racists and complicit others would be a part of. If the object of moral anger is change, then anger is never just a call to "leave me alone." More importantly, it asks, "How might we live 
together?" Moral anger at any political injustice sounds the alarm that a disruption in the community has occurred and expresses the need for repairing the damage. This captures Baldwin's interrelatedness point. Moreover, this is why King noted, 'Our slogan must not be 'Burn, baby, burn.' It must be, 'build, baby, build.' Let us keep going toward ... the realization of the dream of brotherhood and toward the realization of the dream of understanding good will" (King and West 2015: 69). Moral anger at racists and complicit others expresses love by articulating this community message.

\section{Conclusion}

My aim in this essay has been to convince you that moral anger is not only compatible with love but it is also an expression of love. Moreover, while it may be easy to see why moral anger is an expression of self-love, I have hoped to show how it is an expression of agape love. I have done this not only so that we can make proper distinctions and understand the interrelatedness of emotions. More importantly, I hope that my claim can aid us all in evaluating the actions and motives of moral agents who respond to injustices with moral anger. When anger does not show concern for the moral improvement of others, refuses to respect others, and excludes them from the moral community it communicates at best self-love and, at worst, hatred, including self-hatred. Then we have reasons to view such anger as morally suspect. However, truly moral anger in fact shows concern for the moral improvement of others, respects those others, and aims to reform and repair the moral community. We thus have strong reasons to view moral anger as an expression of agape love - a love that this world so desperately needs. 


\section{Notes}

1 These ideas have benefited from audiences at Wesleyan University, Princeton University, University of California, Riverside, and Hofstra University. I am also grateful for the insightful feedback of Alice MacLachlan, Axelle Karera, Jesse Prinz, Berrett Emerick, and Adrienne Martin.

2 The only grounds for loving is because they are human.

3 I do not take Baldwin to speak for all blacks.

4 I do not downplay Murphy's emphasis on "care" here or Margaret Walker's claim in Moral Repair (2006) that anger also expresses confirmation that others value our dignity. However, I want to move from claims only about dignity and respect and offer a more robust account.

\section{References}

Aarts, H. et al. (2010) "The Art of Anger: Reward Context Turns Avoidance Responses to Anger-Related Objects into Approach," Psychological Science, 21(10): 14061410.

Aristotle. (2004) Rhetoric, Jenny Bak (ed.), Mineola, NY: Dover Publications.

Baldwin, J. (1984) Notes of a Native Son, Boston, MA: Beacon Press.

Baldwin, J. (1993) The Fire Next Time, New York: Vintage International.

Baldwin, J. (1998) The Price of the Ticket, New York: St. Martins Press.

Ben-Ze'ev, A. (2001) The Subtlety of Emotions, Cambridge, MA: A Bradford Books.

Brandom, R. (2007) "The Structure of Desire and Recognition. Self-Consciousness and Self-Constitution," Philosophy \& Social Criticism, 33: 127-150.

Butler, J. (1827) Fifteen Sermons Preached at the Rolls Chapel, Cambridge: Hilliard and Brown. http://anglicanhistory.org/butler/rolls.

Fields, D. (2015) All Those Strangers: The Art and Lives of James Baldwin, New York: Oxford University Press.

Flannigan, O. (2018) "Introduction" in M. Cherry and O. Flannigan (eds), The Moral Psychology of Anger, Lanham, MD: Rowman and Littlefield.

Helm, B. (2013) "Love" in E. Zalta (ed.), The Stanford Encyclopedia of Philosophy, http://plato.stanford.edu/archives/fall2013/entries/love. 
Kauppinen, A. (2018) "Valuing Anger" in M. Cherry and O. Flannigan (eds), The Moral Psychology of Anger, Lanham, MD: Rowman and Littlefield.

King, M.L. Jr. and West, C. (2015) The Radical King, New York: Beacon Press.

Lindberg, C. (2008) A Brief History Through Western Christianity, New York: WileyBlackwell.

Lorde, A. (2007) Sister Outsider, New York: Ted Speed Press.

Lorde, A. (1997) “The Uses of Anger," Women's Studies Quarterly 25(1/2): 278-285.

May, S. (2011) Love: A History, New Haven, CT: Yale University Press.

Moseley, A. "Philosophy of Love," Internet Encyclopedia of Philosophy. www.iep.utm.edu/love.

Murphy, J.G. (2003) Getting Even: Forgiveness and Its Limits, New York: Oxford University Press.

Nussbaum, M. (2016) Anger and Forgiveness, New York: Oxford University Press.

Smith, A. (1976) The Theory of Moral Sentiments, Indianapolis, IN: Liberty Fund.

Solomon, R. (2007) True to Our Feelings, New York: Oxford University Press.

X, Malcolm and Breitman, George (1990) "Message to the Grassroots" in Malcolm X Speaks: Selected Speeches and Statements, New York: Grove Weidenfeld. 